\title{
Design Factors influencing Quality of Building Projects in Nigeria: Consultants' Perception
}

Lukumon O Oyedele (Department of Building, National University of Singapore, Singapore), Babatunde E Jaiyeoba (Department of Architecture, Faculty of Environmental Design and Management, Obafemi Awolowo University, Nigeria) and Moshood O Fadeyi (Department of Architecture, Faculty of Environmental Design and Management, Obafemi Awolowo University, Nigeria)

\section{ABSTRACT}

Various factors identified from the literature that can influence quality of building projects in Nigeria have been studied by means of questionnaire survey sent to architects, engineers and quantity surveyors in the industry. From a total response of 107 consultants, the importance of each factor was obtained via severity and frequency responses of the factors. Data analysis includes comparisons of ranking among consultants using severity, frequency and importance indexes, correlation analysis, and percentage rank agreement factor (PRAF) to measure the agreement in the importance ranking among the consultants.

Correlation results between the professionals are architects/ quantity surveyors $(0.75)$, architects/engineers $(0.21)$, and engineers/quantity surveyors $(0.24)$. The percentage rank agreement factor (PRAF) shows that the five most important factors affecting quality are 'design changes' $(78.9 \%)$; 'inadequate involvement of other professionals during the design stage' (78.9\%); 'insufficient and unrealistic constraints of project cost' (71.1\%); 'poor level of commitment to quality improvement among design professionals' $(63.2 \%)$; and 'making design decisions on cost and not value of work' (55.3\%). The results of this study would provide feedback for the clients, project and quality mangers and all the consultants in the industry, so that effective management of quality can be ensured from the conceptual-design stage of the project.

Keywords: Design factors, Quality, Architects, Engineers, Quantity surveyors, Nigeria.

\section{INTRODUCTION}

Quality and quality systems are topics which have been receiving increasing attention worldwide (Lowe and Seymour, 1990; Low, 1992; Walter, 1992; Chan, 1996; Yates and Aniftos, 1997; Docker, 1991; Arditi and Gunaydin, 1997). The finished product in any industry should be manufactured to a required standard, one which provides customer satisfaction and value for money (Chan and Tam, 2000). The high cost of building makes it necessary to ensure quality of the finished product. However, in achieving this quality of the finished product effort must be taken to look at the construction process of the delivery product. The construction process can be divided into project conception, project design and project construction (Okpala and Aniekwu, 1988). Despite the voluminous nature of the existing literature on quality management and construction process, little of it addresses the design factors that can influence the quality of building projects. Yet, it is at the design stage that most decisions affecting the construction, performance and operation of a building can be wielded to optimize the value of the building to its end users (Bourn, 2000). Hartkopf et al. (1986) acknowledged that any failure at the conceptual-design stage of a project might lead to stress factors causing significant problems in the successive stages of the project. Many studies in construction practice have reviewed the implications of inefficient design. Research undertaken by Building Research Establishment (BRE, 1982), in UK has shown that slightly more that fifty per cent of construction faults were caused by design deficiencies. The National Economic Development Office (NEDO, 1987) also adjudged that some two thirds of inadequate qualities on construction sites were due to design inefficiencies. All these point to the fact that design process has great influence in achieving quality of building projects.

This paper reports the finding of a study which was undertaken to determine the design factors influencing quality of building projects in Nigeria from consultants' perspective. A total of 180 experienced consultants, comprising of architects, engineers and quantity surveyors were surveyed in Nigeria. The importance of each factor was computed for all the consultants via severity and frequency responses of the factor. Using a percentage rank agreement factor for the combination of all the consultants, design factors affecting quality of building projects were identified.

\section{DESIGN FACTORS AFFECTING QUALITY OF BUILDING PROJECTS}

One or more design factors influencing quality of building projects or its construction process have been mentioned in the literature, there is however, no general agreement on a set of design factors influencing quality of building projects. From the existing literature discussed below, it was possible to identify fifteen factors that influence quality of building projects. These are shown in the first column of Table 2.

Without doubt, the most important phase in a building's life is the client-briefing stage (Emmitt, 1999). According to Blyth and Worthington (2001), the brief is the gauge at which the rest of the project development process is measured, specifying the building quality among other requirements. Aspects of client briefing which include clarity of project mission, competency of client in terms of ability to brief, make moral decisions, define roles et cetera, have been shown to influence the quality of a project (Nahapiet, 1983; Ferguson and Mitchell, 1986; Bresnen et al., 1990; Naoum, 1991; Naoum and Mustapha, 1995). 
The importance of communication within a team has been emphasized in many studies. Indeed effective communication is the key to good performance (Dozzi et al., 1996) and enables a project to be completed faster (Walker, 1998). Alarcon and Ashley (1992) went so far to state that communication planning and control is the only factor that influences all performance outcomes of a project. Similarly, team-related issues such as team building, teamwork, team organization, team turnover, and team experience are often recognized as crucial factors for project performance (Sanvido et al., 1992), yet at present most of what is known about design activity in general comes from studies of individual designers (Cross and Clayburn-Cross, 1996).

Lack of project definition might affect quality of building projects. Hersey and Blanchard (1982) have identified the importance of clear goal definition to project success. Sidwell (1984) echoes this by advocating that clients who get the best results are those who provide the building team with well-defined specialized needs.

Arditi and Gunaydin (1997) noted that quality of drawings and specifications received from the designer affect the quality in the design and construction phases and consequently the quality of the constructed facility. Defective designs bring adverse impact on project performances and the participants (Andi and Minato, 2003) and are responsible for many construction failures (Sowers, 1993). Design changes can also affect the aesthetics and functional aspects of the building, the scope and nature of work, or its operational aspects (Love and Irani, 2003). Hiyassat (2000) noted that design changes during construction process causes delay, variation order and claim. In addition, the design must be reviewed to ensure that the project is constructible and the desired quality is achieved. According to the Construction Management Association of America (CMMA, 1999) constructability reviews should take place periodically throughout the design performance period. It is a very good system of detecting errors, omissions and checkpoints to make sure that the constructed facility is of a good quality and standard. Design codes and standards might have effects on the quality of building as well. Kubal (1994) claims that regulations controlling the construction process are more restrictive than in most manufacturing and service industries.

Also of importance are the insufficient and unrealistic constraints of project time and cost. Ferguson and Mitchell (1986) highlighted that if design must be produced quickly, quality may suffer, unless an appropriate contracting system which is quick to build has been made. Pressure of schedule can result into shoddy workmanship and errors.

Furthermore, the performance of individual participants remains important because overall project performance is a function of the performance of each participant (Liu and
Walker, 1998). Poor levels of commitment to quality can also influence the quality of the constructed project.

From the existing literature discussed above, none has comprehensively identified and studied design factors in relation to quality of building projects. Studying this in a developing country such as Nigeria where there is not comprehensive quality system and from the viewpoints of construction professionals, who are important stakeholders in any construction industry, are essential steps towards establishing methods for real quality improvement. All these are existing gaps in knowledge, which indicate why this present study is important and necessary.

\section{RESEARCH METHOD}

\section{The Questionnaire}

The fifteen factors identified from the literature above form part of the questionnaire survey. A preliminary pilot study aimed at providing information for the development of the questionnaire was conducted with the consultants in the industry. The respondents involved three architects, two engineers and one quantity surveyor, all having an average of seventeen years experience. On average they had handled more than twenty-five projects as at February 2003. The questionnaire was refined a number of times, based on the consultants' feedback before it was used finally used for the survey carried out at the data collection stage. It should be noted that the word 'consultant' in this paper refers to professional architect, engineer or quantity surveyor.

The questionnaire consists of two sections. Section 1 consists of the respondent's personal particulars such as profession of respondent, years of experience, academic qualification and number of projects executed. In Section 2 , each respondent was asked to rate the severity of each factor on how badly it affects the quality of a building project on a five-point Likert scale ranging from 1 to 5 , where 1 represents 'not severe', and 5 represents 'extremely severe'. The respondents were also asked to rate the frequency of occurrence of each factor in affecting quality of a building project on a five-point Likert scale ranging from 1 to 5 , where 1 represents 'not frequent' and 5 represents 'extremely frequent'.

\section{Sample Characteristics}

A total of 180 experienced Nigerian consultants comprising sixty each, of architects, engineers and quantity surveyors were targeted in the survey. Architects were randomly drawn from the list of professional architects in the Nigerian Institute of Architects (NIA) members' directory (2000). The same approach was also used for the engineers and quantity surveyors using the Nigeria Society of Engineers (NSE) members' directory (2001) and Nigerian Institute of Quantity surveyors (NIQS) members' directory (2002) respectively. The engineers are comprised of civil/structural, mechanical and electrical engineers. The questionnaires 
were sent to some respondents through electronic mail and postage, while the remaining were delivered in person to the respondents. Table 1 shows the summary of the sample response of the questionnaire survey.

\begin{tabular}{llllll|}
\hline Consultants & $\begin{array}{l}\text { Number } \\
\text { distributed }\end{array}$ & $\begin{array}{l}\text { Number } \\
\text { of responses }\end{array}$ & $\begin{array}{l}\text { Percentage } \\
\text { return }\end{array}$ & $\begin{array}{l}\text { Average years } \\
\text { of Experience }\end{array}$ & $\begin{array}{l}\text { Average number of } \\
\text { Projects involved with }\end{array}$ \\
\hline Architects & 60 & 41 & 68.3 & 21 & above 25 \\
Civil/Structural & 30 & 21 & 70 & 19 & above 25 \\
Mechanical & 15 & 9 & 60 & 15 & above 25 \\
Electrical & 15 & 7 & 46.7 & 11 & $20-25$ \\
Total & & & & & \\
Engineers & 60 & 37 & 61.7 & 14 & above 25 \\
Quantity & & & & & $20-25$ \\
Surveyors & 60 & 29 & 48.3 & 13 & above 25 \\
Total & 180 & 107 & 59.4 & 16 & \\
\hline
\end{tabular}

Table 1: Sample Response of Questionnaire Survey

From the Table 1, the average response rates were $68.3 \%$, $61.7 \%$ and $48.3 \%$ for the architects, engineers and quantity surveyors respectively. This was considered adequate for analysis based on the assertion by Moser and Kalton (1971) that the result of a survey could be considered as biased and of little importance if the return rate was lower than thirty to forty per cent.

\section{DATAANALYSIS AND RESULTS}

The importance of each factor was computed by multiplying the severity and frequency of each factor. This is given in equation 1 below.

$$
\text { Importance }(I)=\text { Severity }(S) X \text { Frequency }(F)
$$

The data was analyzed using the following methods:

1. Reliability of data obtained to test the internal consistency of the scale used for measuring the factors.

2. Comparison of ranking among consultants using severity, frequency and importance indexes.

3. Correlation analysis to measure degree of correlation among all consultants.

4. Percentage rank agreement factor (PRAF), to measure the agreement in the importance ranking among the consultants.

\section{Reliability}

Reliability analysis was used to study the properties of measurement scales and the items that constitute them. The Cronbach alpha of internal consistency reliability in the Statistical Package for Social Sciences (SPSS) was used. The alpha has a reliability coefficient which varies from 0 to 1 ; the higher the alpha the greater the internal consistency of reliability. The alpha should be greater than 0.7 . The result of the Cronbach alpha for this data is 0.887 .

\section{Comparison of ranking among consultants}

Severity index, frequency index and importance index were used to rank the relative severity, frequency and importance of each factor respectively. All these indexes were derived according to the formula described by Kometa et al. (1994) and Chan and Kumaraswamy (2002) for relative importance index. The indexes could be expressed mathematically as follows:

$$
\begin{aligned}
\text { Severity Index }(S I) & =\left(\frac{\sum(s)}{N S}\right) \times 100 \% \\
\text { Frequency Index (FI) } & =\left(\frac{\sum(f)}{N F}\right) \times 100 \% \\
\text { Importance Index (II) } & =\left(\frac{\sum(s f)}{N S F}\right) \times 100 \%
\end{aligned}
$$

Where $s$ and $f$ are severity and frequency rating respectively ranging from 1 to $5 ; S$ and $F$ are the highest severity and frequency rating respectively, that is 5 ; and $N$ is the total number of responses for that particular factor.

\begin{tabular}{|c|c|c|c|c|c|c|}
\hline Factors & SI & SR & $\mathrm{FI}$ & FR & II & IR \\
\hline Poor client briefing & 72.14 & 6 & 62.14 & 9 & 44.43 & 9 \\
\hline $\begin{array}{l}\text { Inadequate pre-design } \\
\text { project meetings }\end{array}$ & 69.29 & 10 & 60.00 & 12 & 43.57 & 10 \\
\hline Lack of project definition & 70.00 & 7 & 54.07 & 15 & 40.14 & 14 \\
\hline Design defects & 73.57 & 4 & 60.74 & 11 & 44.71 & 8 \\
\hline $\begin{array}{l}\text { Inadequate technical } \\
\text { knowledge }\end{array}$ & 72.86 & 5 & 60.00 & 12 & 45.43 & 7 \\
\hline Poor specification & 70.00 & 7 & 56.43 & 14 & 41.43 & 12 \\
\hline Design changes & 70.00 & 7 & 71.43 & 2 & 50.14 & 3 \\
\hline $\begin{array}{l}\text { Insufficient and } \\
\text { unrealistic constraints } \\
\text { of project time }\end{array}$ & 65.71 & 14 & 73.57 & 1 & 50.57 & 2 \\
\hline $\begin{array}{l}\text { Insufficient and unrealistic } \\
\text { constraints of project cost }\end{array}$ & 74.07 & 3 & 66.43 & 5 & 48.43 & 6 \\
\hline $\begin{array}{l}\text { Inadequate involvement } \\
\text { ofother professionals and } \\
\text { teamwork during the } \\
\text { design stage }\end{array}$ & 67.14 & 12 & 67.14 & 4 & 50.00 & 4 \\
\hline $\begin{array}{l}\text { Lack of constructability } \\
\text { review of design }\end{array}$ & 64.62 & 15 & 62.31 & 8 & 39.00 & 15 \\
\hline $\begin{array}{l}\text { Poor communication } \\
\text { among design team }\end{array}$ & 68.89 & 11 & 61.54 & 10 & 40.29 & 13 \\
\hline $\begin{array}{l}\text { Making design decisions } \\
\text { on cost and not } \\
\text { value of work }\end{array}$ & 77.04 & 1 & 66.15 & 6 & 48.86 & 5 \\
\hline $\begin{array}{l}\text { Poor level of commitment } \\
\text { to quality improvement } \\
\text { among design professionals }\end{array}$ & $\begin{array}{l}76.30 \\
\text { s }\end{array}$ & 2 & 71.11 & 3 & 53.14 & 1 \\
\hline $\begin{array}{l}\text { Effect of design code and } \\
\text { standards on quality }\end{array}$ & 65.93 & 13 & 65.19 & 7 & 42.29 & 11 \\
\hline
\end{tabular}

Table 2, 3 and 4 shows the severity, frequency and importance indexes and ranks of the architects, engineers and quantity surveyor responses respectively.

Table 2: Indexes and Ranks of Architects' responses 


\begin{tabular}{|c|c|c|c|c|c|c|}
\hline Factors & SI & SR & $\mathrm{FI}$ & FR & II & $\mathbb{R}$ \\
\hline Poor client briefing & 66.36 & 12 & 53.64 & 11 & 35.48 & 11 \\
\hline $\begin{array}{l}\text { Inadequate pre-design } \\
\text { project meetings }\end{array}$ & 60.00 & 14 & 64.55 & 2 & 36.70 & 8 \\
\hline Lack of project definition 72 & 72.73 & 2 & 54.55 & 9 & 38.96 & 6 \\
\hline Design defects & 65.45 & 13 & 50.00 & 14 & 31.48 & 15 \\
\hline $\begin{array}{l}\text { Inadequate technical } \\
\text { knowledge }\end{array}$ & 72.73 & 2 & 59.09 & 6 & 41.74 & 4 \\
\hline Poor specification & 68.18 & 9 & 50.00 & 14 & 33.22 & 14 \\
\hline Design changes & 69.09 & 7 & 62.73 & 3 & 42.43 & 2 \\
\hline $\begin{array}{l}\text { Insufficient and } \\
\text { unrealistic constraints } \\
\text { of project time }\end{array}$ & 54.55 & 15 & 70.48 & 1 & 35.13 & 12 \\
\hline $\begin{array}{l}\text { Insufficient and unrealistic } 7 \\
\text { constraints of project cost }\end{array}$ & 71.82 & 5 & 60.91 & 5 & 43.13 & 1 \\
\hline $\begin{array}{l}\text { Inadequate involvement } 7 \\
\text { of other professionals and } \\
\text { teamwork during the } \\
\text { design stage }\end{array}$ & 70.00 & 6 & 57.27 & 7 & 41.91 & 3 \\
\hline $\begin{array}{l}\text { Lack of constructability } \\
\text { review of design }\end{array}$ & 68.00 & 11 & 62.11 & 4 & 37.04 & 7 \\
\hline $\begin{array}{l}\text { Poor communication } \\
\text { among design team }\end{array}$ & 66.36 & 8 & 52.73 & 13 & 34.43 & 13 \\
\hline $\begin{array}{l}\text { Making design } \\
\text { decisions on cost and } \\
\text { not value of work }\end{array}$ & 68.18 & 9 & 54.29 & 10 & 35.65 & 10 \\
\hline $\begin{array}{l}\text { Poor level of commitment } \\
\text { to quality improvement } \\
\text { among design professionals }\end{array}$ & $\begin{array}{l}73.64 \\
\text { als }\end{array}$ & 1 & 53.33 & 12 & 36.70 & 8 \\
\hline $\begin{array}{l}\text { Effect of design code and } \\
\text { standards on quality }\end{array}$ & 72.73 & 2 & 57.27 & 7 & 40.00 & 5 \\
\hline
\end{tabular}

\begin{tabular}{|llll|}
\hline Consultants & $\begin{array}{l}\text { Architects' } \\
\text { Importance }\end{array}$ & $\begin{array}{l}\text { Engineers' } \\
\text { Importance }\end{array}$ & $\begin{array}{l}\text { Quantity Surveyors' } \\
\text { Importance }\end{array}$ \\
\hline Architects' Importance & 1.00 & & \\
Engineers' Importance & 0.21 & 1.00 & 1.00 \\
$\begin{array}{l}\text { Quantity surveyors' } \\
\text { Importance }\end{array}$ & $0.75^{* *}$ & 0.24 & \\
\hline "'Correlation is significant at the 0.01 level (2-tailed). & \\
\hline
\end{tabular}

Table 5: Spearman rank correlation coefficients of consultants' importance

\section{Percentage rank agreement factor (PRAF)}

To have a general agreement in the ranking of all factors, the rank agreement factor (RAF) and percentage rank agreement factor (PRAF) (Okpala and Aniekwu, 1988, Elinwa and Buba, 1994; Adams, 1997; Elinwa and Joshua, 2001, Chan and Kumaraswamy, 2002) was used to measure quantitatively the agreement in the importance ranking among the architects, engineers and quantity surveyors.

$$
\begin{gathered}
R A F=\frac{\sum A E Q}{N} \\
P R A F=\frac{R A F_{\max }-R A F_{i}}{R A F_{\max }} \times 100 \%
\end{gathered}
$$

Where $R A F_{\text {max }}=$ maximum $R A F ; \mathrm{N}=$ number of variable factors ranked; and $\sum A E Q=$ sum of the order of rankings by architects, engineers and quantity surveyors. An absolute difference in rank of 2, for example, implies that the groups agreed more than when the absolute difference is 3 . The rank agreement factor (RAF) can be $>1$, with a higher factor implying greater disagreement (Okpala and Aniekwu, 1988; Elinwa and Joshua, 2001). For twenty-three factors that are important in influencing quality of building projects, the maximum $R A F_{\max }=2.53$. A RAF of zero implies perfect agreement. This result of this rank agreement factor for the consultants is shown in Table 6 and Figure 1 below.

\section{DISCUSSIONS OF THE RESULTS}

In terms of design factors that are severe to quality of building projects, 'poor level of commitment to quality improvement among design professionals', 'insufficient and unrealistic constraints of project cost' and 'inadequate technical knowledge' are the three severe factors common to all the professionals within their first five ranked severe factors. From the architects' ranking (Table 2) the factors were ranked second, third and fifth respectively. The engineers ranked the factors first, fifth and second respectively (Table 3), while the quantity surveyors ranked the factors second, first and fifth (Table 4). This means that all the professionals agree that they need to be more committed to quality right from the design stage so that high quality buildings could be constructed. In addition, they agreed that having high technical knowledge would improve quality of buildings within the industry. This would help 


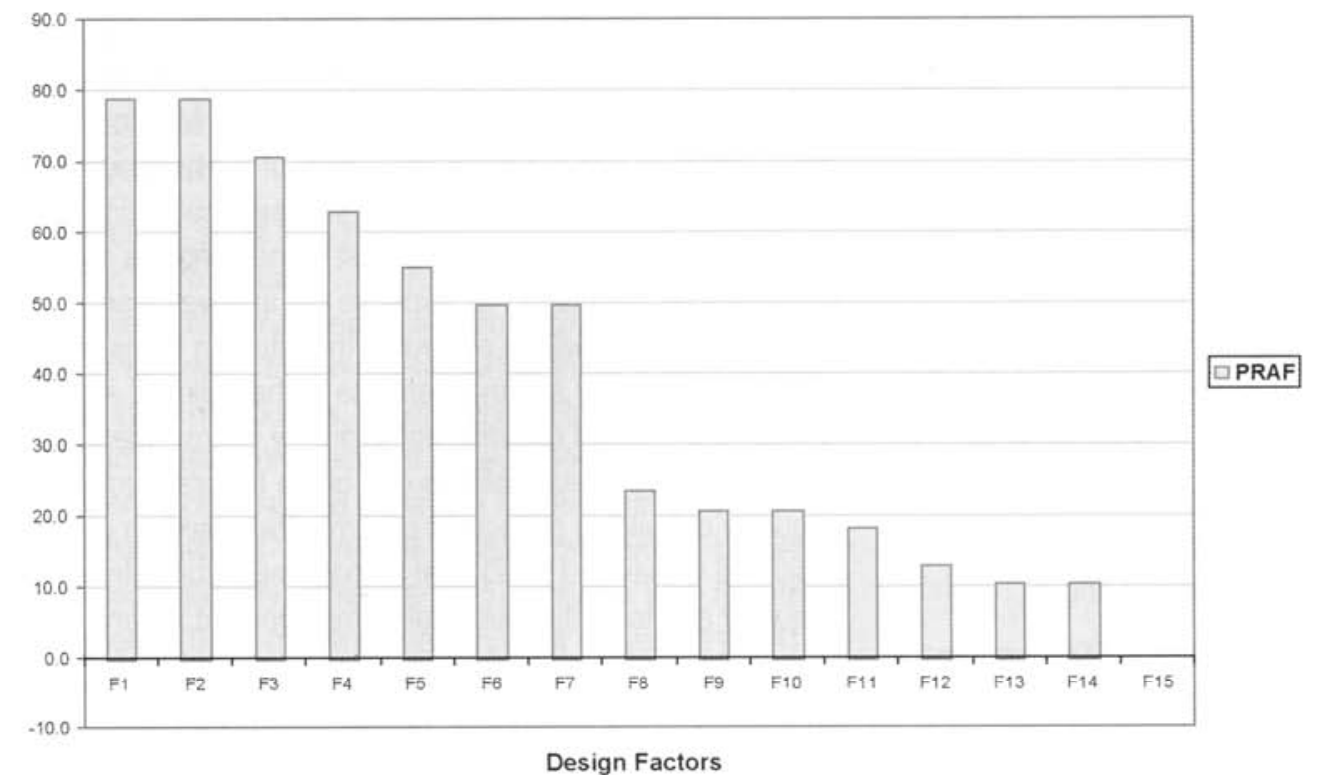

Figure 1: Percentage agreement factor of factors affecting quality of building projects in Nigeria.

Note: F1 = Design changes, F2 = Inadequate involvement of other professionals during the design stage, F3 = Insufficient and unrealistic constraints of project cost, F4 = Poor Level of commitment among design professionals, F5 = Making design decisions on cost and not value of work. F6 = Insufficient and unrealistic constraints of time, F7 = Inadequate technical knowledge, F8 = Inadequate pre-design project meetings, F9 $=$ Design defects, $\mathrm{F} 10=$ Lack of constructability review, F11 $=$ Effect of design codes and Standards on quality, F12 $=$ Poor client briefing, F13 = Lack of project definition, F14 = Poor specification, F15 = Poor communication among participants

\begin{tabular}{|c|c|c|c|c|c|c|c|}
\hline Factors & $\begin{array}{l}\text { Architect } \\
\text { ranking }\end{array}$ & $\begin{array}{l}\text { Engineer } \\
\text { ranking }\end{array}$ & $\begin{array}{l}\text { Quantity } \\
\text { Surveyor } \\
\text { ranking }\end{array}$ & $\begin{array}{l}\text { Sum of } \\
\text { ranking } \\
\sum A Q E\end{array}$ & RAF & PRAF & $\begin{array}{l}\text { Ranking } \\
\text { order }\end{array}$ \\
\hline Design changes & 3 & 2 & 3 & 8 & 0.53 & 78.9 & 1 \\
\hline $\begin{array}{l}\text { Inadequate } \\
\text { involvement of } \\
\text { other professionals } \\
\text { and team work during } \\
\text { the design stage }\end{array}$ & & 3 & 1 & 8 & 0.53 & 78.9 & 1 \\
\hline $\begin{array}{l}\text { Insufficient and } 6 \\
\text { unrealistic constraints } \\
\text { of project cost }\end{array}$ & & 1 & 4 & 11 & 0.73 & 71.1 & 3 \\
\hline $\begin{array}{l}\text { Poor level of } \\
\text { commitment to quality } \\
\text { improvement among } \\
\text { design professionals }\end{array}$ & & 8 & 5 & 14 & 0.93 & 63.2 & 4 \\
\hline $\begin{array}{l}\text { Making design } \\
\text { decisions on cost } \\
\text { and not value of work }\end{array}$ & 5 & 10 & 2 & 17 & 1.13 & 55.3 & 5 \\
\hline $\begin{array}{l}\text { Insufficient and } \\
\text { unrealistic constraints } \\
\text { of project time }\end{array}$ & & 12 & 5 & 19 & 1.27 & 50.0 & 6 \\
\hline $\begin{array}{l}\text { Inadequate } \\
\text { technical knowledge }\end{array}$ & 7 & 4 & 8 & 19 & 1.27 & 50.0 & 6 \\
\hline $\begin{array}{l}\text { Inadequate and } \\
\text { poor pre-design } \\
\text { project meetings }\end{array}$ & 10 & 8 & 11 & 29 & 1.93 & 23.7 & 8 \\
\hline Design defects & 8 & 15 & 7 & 30 & 2.00 & 21.1 & 9 \\
\hline $\begin{array}{l}\text { Lack of } \\
\text { constructability } \\
\text { review of design }\end{array}$ & 15 & 7 & 8 & 30 & 2.00 & 21.1 & 9 \\
\hline $\begin{array}{l}\text { Effect of design } \\
\text { code and standards } \\
\text { on quality }\end{array}$ & 11 & 5 & 15 & 31 & 2.07 & 18.4 & 11 \\
\hline Poor client briefing & 9 & 11 & 13 & 33 & 2.20 & 13.2 & 12 \\
\hline $\begin{array}{l}\text { Lack of project } \\
\text { definition }\end{array}$ & 14 & 6 & 14 & 34 & 2.27 & 10.5 & 13 \\
\hline Poor specification & 12 & 14 & 8 & 34 & 2.27 & 10.5 & 13 \\
\hline $\begin{array}{l}\text { Poor communication } \\
\text { among design team }\end{array}$ & 13 & 13 & 12 & 38 & 2.53 & 0.0 & 15 \\
\hline
\end{tabular}

Table 6: Percentage rank agreement factor for all the Consultants 
them in the choice of appropriate materials and technology, specification writing and quality of the design documents for the building.

Examining the frequency of the factors, 'design changes' and 'insufficient and unrealistic constraints of projects cost' are the frequent factors that are ranked in common within the first five factors of all the professionals. It was ranked second and fifth respectively by the architects, third and fifth respectively by the engineers, and first and second by the quantity surveyors. 'Insufficient and unrealistic constraints of project time' was ranked to be the most frequent by the architects and engineers while the quantity surveyors ranked it seventh. All these are shown in Table 2, 3 and 4.

In terms of importance, 'design changes' and 'inadequate involvement of other professionals and team work during design stage' were ranked within the five most important factors common to all professionals. From the percentage rank agreement factor (PRAF) as shown in Table 6, these two factors were also ranked highest. Design changes had been acknowledged by Elinwa and Joshua (2001) as one of the critical factors causing time-overrun of building projects in Nigeria. A further investigation with about forty per cent of the respondents of the survey indicated that design changes mostly occur because of the continuous changes in the client brief despite the fact that design has been completed and construction work is in progress. This according to them affects the orderly development of work and causes delay which in turn demand more cost that most clients are ready to bear and as such, affects the quality of building projects that are delivered. O'Leary (1992) commonly confirmed this within any construction processes, that design changes are generally disruptive of the orderly progress of work, an economic burden to both owner and contractor and are often symptomatic of someone's failure to properly fulfill his/her function in the construction process. Some of the professionals agree that they needed to make their design more flexible to accommodate these changes.

With 'inadequate involvement of other professionals and team work during design stage', also having the highest PRAF, it confirmed the result of Gunaydin's (1995) study of Total Quality Management (TQM) in the US, where extent of team work of parties participating in the design phase was found to be the most important factor affecting quality. This result shows that early involvement and teamwork during design stage among parties such as architects, structural, electrical, mechanical, environmental and civil engineers is crucial in achieving quality of building projects.

Other factors that were generally agreed to be important in affecting quality of building projects in Nigeria include 'insufficient and unrealistic constraints of project cost', 'poor level of commitment to quality improvement among design professionals' and 'making design decisions on cost and not value of work'. They were ranked third, fourth and fifth respectively. Insufficient project estimates had been shown to affect quality of design documents (Andi and Minato, 2003), which in turn will affect the quality of the building projects. Arditi and Gunaydin (1997) stressed that taking measures to achieve high quality cost money and this cost should not be considered an expense but an investment because the effect will be evident in the future in terms of the durability, safety and maintenance of the building. Also having 'poor level of commitment to quality improvement among design professionals' as one of the factors crucial to quality of building projects, it confirms the assertion of Arditi and Gunaydin (1997), that management commitment to quality and to continuous quality improvement is very important if quality is to be achieved.

An analysis of the relationship between the consultants shows a strong and significant level of agreement between the architects and quantity surveyors views, with the correlation coefficient of 0.75 (Table 5). This was not the same with the architect/engineer and engineer/quantity surveyor having the values of 0.21 and 0.24 respectively.

\section{FURTHER DIRECTION AND LIMITATIONS}

An obvious limitation to our study is the use of only a quantitative approach through questionnaire survey in conducting this research. Though this has provided some foundation for further studies, there is a need for a qualitative approach to the study such as the use of case studies in studying the effect of design on quality of buildings. This would allow the issues to be explored more deeply. In addition, there is a need to view the study from contractor's perspective who worked on the successive stages of the design phase. Continued research is also needed to examine how well the concept of Total Quality Management can be implemented in a developing country such as Nigeria during the phases of all projects which are inclusive of the design phase. There is also a need to establish an empirical link between design process in determining final quality of buildings in terms of technical performance such as functionality, thermal, acoustic, lighting, indoor-air quality and building integrity.

\section{CONCLUSION}

This research reports the findings of a study that was undertaken to determine the design factors influencing quality of building projects in Nigeria from consultants' perspective. Design factors influencing quality were identified from the literature and studied by means of a questionnaire survey sent to architects, engineers and quantity surveyors. The importance of each factor was computed for all the consultants via severity and frequency responses of the factors. Data analysis includes comparisons of ranking among consultants using severity, frequency and importance indexes. Correlation analysis was 
used to measure degree of correlation among all consultants and percentage rank agreement factor (PRAF) was used to measure the agreement in the importance ranking among the consultants.

The results show that 'poor level of commitment among design professionals', 'insufficient and unrealistic constraints of project cost' and 'inadequate technical knowledge' are the three severe factors ranked within the first five common to all the professionals. 'Design changes', 'insufficient and unrealistic constraints of projects cost' are the two frequent factors ranked within the first five common to all the professionals. There was a strong relationship between architects/quantity surveyors (0.75), while for both architects/ engineers $(0.21)$ and engineers/quantity surveyors $(0.24)$ the relationships were low.

The percentage rank agreement factor (PRAF) shows that the five most important factors affecting quality are 'design changes' (78.9\%); 'inadequate involvement of other professionals during the design stage' (78.9\%); 'insufficient and unrealistic constraints of project cost' (71.1\%); 'poor level of commitment to quality improvement among design professionals' (63.2\%) and 'making design decisions on cost and not value of work' (55.3\%).

The findings of this research would provide feedback for the clients, project and quality mangers, architects, engineers etc. so that effective management of quality can be ensured from the conceptual-design stage of the project. The results can also be used as the basis of a national and international study in other countries by extending the study in collaboration with fellow researchers in these areas. Such an extension will aid the understanding of managing quality in different cultures, particularly in developing countries.

\section{ACKNOWLEDGEMENT}

The authors wish to express their sincere gratitude to Arc. E.O. Somide of Oso Somide and Associates, Lagos Nigeria and Mr Herry Abdillah of Mechanical Engineering, National University of Singapore (NUS) for their assistance in data collection and analysis respectively. We would also like to thank Mr Afful Benjamin and Ashvin Parameswaran both of whom are from the English Department, NUS for their efforts in editing this manuscript. Finally, we are grateful to $\mathrm{Mr}$ Sujuandy bin Suppa'at of Computer Center (NUS) and Mrs Husseinah K. Oyedele for their encouragement and moral support during the writing of this manuscript.

\section{REFERENCES}

Adams, O. (1997). Contractor development in Nigeria: perceptions of contractor and professionals. Construction management and Economics, 15, 95-108.

Alarcon, L.F., \& Ashley, D.B. (1992). Project performance modeling: A methodology for evaluating project execution strategies. (Source Document 80).
The University of Texas at Austin, The Construction Industry Institute.

Andi and Minato T. (2003). Design documents quality in the Japanese construction industry: factors influencing and impacts on construction process. International Journal of Project Management, 21 (7), 537-546.

Arditi, D. and Gunaydin, H.M. (1997). Total quality management in construction process. International Journal of Project Management, 15 (4), 235-43.

Blyth, A. and Worthington, J. (2001). Managing the brief for better design. Spoon press, Taylor and Francis Group, New York.

Bourn, J. (2001). Modernising construction: Report by the Comptroller and Auditor General, HC 87 Session 20002001, 11 January 2001. Stationery Office, London

Bresnen, M.J.; Haslam, C.O.; Bryman, A.E. and Keil E.T. (1990). Performance on site and the building client. Occasional Paper, 42. Chartered Institute of Building, Ascot.

Building Research Establishment (BRE), (1982). Quality in Traditional Housing, An Investigation into faults and their Avoidance. BRE Garston.

Chan, A.P.C. (1996). Quality assurance in the construction industry. Architecture Science Review, 39 (2), 107-12.

Chan, A. P. C. and Tam, C. M. (2000). Factors affecting quality of building projects in Nigeria. International of Journal of Quality and Reliability Management, 17 (4/5), 423-441.

Chan, D. M. W. and Kumaraswamy M. M. (2002).

Compressing construction durations: lessons learned from Hong Kong building projects. International Journal of Project Management, 20 (1), 23-35.

Construction Management Association of America (CMMA, 1999). Quality Management Guidelines 2000 Edition. CMMA, USA.

Cross, N. and Clayburn-Cross, A. (1996). Observations of teamwork and social processes in design. In Analyzing design activity, Cross, N., Christiaans, H. and Dorst, K. (eds), J. Wiley and Sons, 291-317.

Docker, P.B. (1991). Quality assurance standard: for the building and construction industry. South Australian Builder, March 15-17.

Dozzi, P., Hartman, F., Tidsbury, N., \& Ashrafi, R. (1996). More stable owner-contractor relationship. Journal of Construction Engineering and Management, ASCE, 122 (1), 30-35.

Elinwa, A.U., and Buba, S.A. (1993). Cost factors in Nigeria. Journal of Construction Engineering and Management, ASCE, 119(4), 698-713. 
Elinwa, A.U. and Joshua, M. (2001). Time overrun factors in Nigeria construction industry. Journal of Construction Engineering and Management, ASCE, 127(5), 419- 25.

Emmitt, S. (1999). Architectural management in practice, Addison Wesley, Longman, England.

Ferguson, I. and Mitchell, E. (1986). Quality on site. B.T. Batsford Ltd. London.

Gunaydin, H. M. (1995) TQM in the construction industry. MS thesis, Illinois Institute of Technology, Chicago, IL.

Hartkopf, V.; Loftness, V. and Mill, P.A.D. (1986). Integration for Performance. In R.D. Rush (ed.). The Building Systems Integration Handbook, Butterworths-Heineman, Boston.

Hersey, P. and Blanchard, K. (1982). Management of Organizational Behavior: Utilizing human Resources, 4th ed. Prentice-Hall International, Englewood Cliffs, NJ.

Hiyassat, M.A.S. (2000). Applying the ISO standards to a construction company: a case study. International Journal of Project Management, 18(4), 275-280.

Kometa, S.T., Olomolaiye, P.O. and Harris F.C. (1994). Attribute of UK construction clients influencing project consultants' performance. Construction Management and Economics, 12 (5), 433-443.

Kubal, M.T. (1994). Engineered Quality in Construction. McGraw-Hill, New York.

Liu, A.M.M. and Walker, A. (1998). Evaluation of project outcomes. Construction Management and Economics, 16, 209-19.

Love P.E.D. and Irani Z. (2003). A project management quality cost information system for the construction industry. Information \& Management, 40(7), 649-661.

Low, S.P. (1992). Quality assurance: technical provisions and implementation for the Singapore construction industry. Building, Singapore Institute of Builders Journal, February, 22-32.

Lowe, S.P. and Seymour, D. (1990). The quality debate. Construction management and Economics, 8 (1), 13-29.

Moser C.A. and Kalton G. (1971). Survey methods in social investigation. Heinemann Educational, UK

Naoum, S.G. (1991). Procurement and project performance. Occasional paper, 45. The Chartered Institute of Building, Ascot.

Naoum, S.G., and Mustapha, F.H. (1995). Influences of the client designer and procurement method on project performance. Proceedings of CIB W92 Symposium East meets West, 221-8.

National Economic Development Office (NEDO) (1987).
Achieving Quality on Building Sites, NEDO, London.

Nigerian Institute of Architects (NIA) (2000). Members' Directory, NIA, Lagos Nigeria.

Nigerian Institute of Quantity surveyors (NIQS) (2000). Members' Director, NIQS, Lagos Nigeria.

Nigeria Society of Engineers (NSE) (2001). Members' directory, NSE, Lagos Nigeria.

Okpala, D.C. and Aniekwu A.N. (1988). Causes of high costs of construction in Nigeria. Journal of Construction Engineering \& Management 114 (2), 233-44.

O'Leary A.F. (1992). Construction Administration in Architectural Practice. McGraw-Hill, Inc. USA.

Sanvido, V., Grobler, F., Parfitt, K., \& Guvenis, M. (1992) Critical success factors for construction projects. Journal of Construction Engineering and Management, ASCE, 118 (1), 94-111.

Sidwell, A.C. (1984). The time performance of construction projects. Architectural Science Review, 27, 85-91.

Sowers, G.F. (1993). Human factors in civil and geotechnical engineering failures. Journal of Geotechnical Engineering, 119 (2), 238-56

Walker, D.H.T. (1994). An investigation into factors that determine building construction time performance. PhD thesis, Royal Melbourne Institute of Technology, Melbourne.

Walker D.H.T. (1998). The contribution of client representative to the creation and maintenance of good project inter-team relationships. Engineering, Construction and Architectural Management, 5(1), 51-7.

Yates, J.K. and Aniftos, S. (1997). International standards and construction. Journal of Construction Engineering and Management, 123 (2) 127-137. 